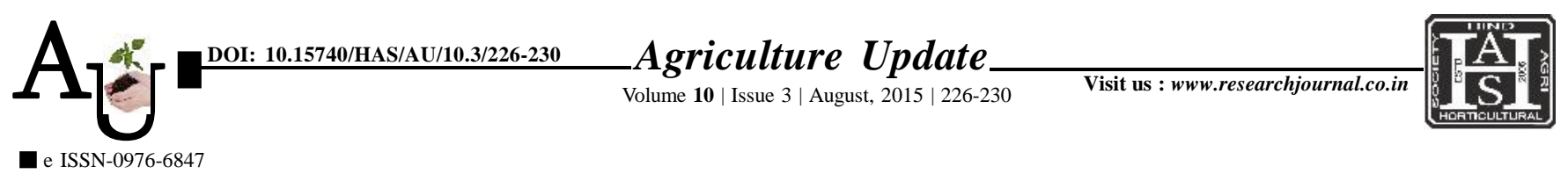

\title{
Research article: Problem faced by the gender in carrying out the practices in paddy and sugarcane crops cultivation
}

\author{
I PARMESHWARI B. PAWAR, VAISHALI R. SHITRE AND R.D. PANDYA
}

Article Chronicle: Received :

24.06.2015;

Revised :

10.07.2015;

Accepted :

11.08 .2015

KeY Words :

Problem, Gender, Paddy, Sugarcane
SUMMARY : The problem refers to the item of difficulty perceived by gender that had carrying out the paddy and sugarcane crops cultivation. Many improved crops cultivation technologies were evolved but due to certain reason farmers are not able to perform it efficiently. Considering this as bottleneck, investigator had tried to find out the crusial problems which prevent the gender to perform various roles as well while taking decision in paddy and sugarcane crops cultivation. The various problems which faced by them were gathered from the respondents. The non-availability of labour in time was reported as major problem by men and ranked first followed by, non-availability of critical inputs got second rank, lack of security scored third rank, lack of skilled labour ranked fourth, extensive work load ranked fifth, unfavourable weather condition ranked sixth, lack of finance ranked seventh, lack of scientific knowledge ranked eighth, lack of moral support ranked ninth, lack of interest got tenth rank, lack of social support ranked eleventh, lack of confidence ranked twelfth, non-availability of implements in time ranked thirteenth and scarcity of irrigation and lack of foresight to conduct the operation ranked fourteenth. In case of women, the non-availability of labour in time was their major problem and ranked first fallowed by, extensive work load got second rank, lack of security scored ranked third, ranked fourth, lack of skilled labour, ranked fifth, lack of scientific knowledge ranked sixth, unfavourable weather condition ranked seventh, lack of finance ranked eighth, lack of confidence ranked ninth, lack of moral support got tenth rank, lack of social support ranked eleventh, lack of interest ranked twelfth, non-availability of implements in time ranked thirteenth, scarcity of irrigation ranked fourteenth and lack of foresight to conduct the operation ranked fifteenth.

How to cite this article : Pawar, Parmeshwari B., Shitre, Vaishali R. and Pandya, R.D. (2015). Problem faced by the gender in carrying out the practices in paddy and sugarcane crops cultivation. Agric. Update, 10(3): 226-230.
Author for correspondence :

\section{PARMESHWARI B.}

PAWAR

Department of

Extension Education,

K.K. Wagh College of

Agriculture, NASHIK

(M.S.) INDIA

Email: pari2805@

rediffmail.com

See end of the article for

authors' affiliations 